\title{
Analysis of a severe air pollution episode in India during Diwali festival - a nationwide approach
}

\author{
Nandita D. GANGULY ${ }^{1}$, Chris G. TZANIS ${ }^{2 *}$, Kostas PHILIPPOPOULOS ${ }^{2}$ and Despina DELIGIORGI ${ }^{2}$ \\ ${ }^{1}$ Department of Physics, St. Xavier's College, Ahmedabad-380009, Gujarat, India \\ ${ }^{2}$ Section of Environmental Physics and Meteorology, Department of Physics, National and Kapodistrian University \\ of Athens, University Campus, 15784 Athens, Greece \\ *Corresponding author; email: chtzanis@phys.uoa.gr
}

Received: December 7, 2017; accepted: June 17, 2019

\begin{abstract}
RESUMEN
En años recientes, los episodios de contaminación del aire han sido motivo de gran preocupación a nivel mundial, dado el incremento tanto en su frecuencia como en su intensidad. Un episodio particularmente alarmante de alta contaminación se observó en algunas partes de la India entre los últimos días de octubre y los últimos días de noviembre de 2016. El índice de calidad del aire pasó de deficiente a muy malo en el norte y oeste de la India, mientras que fue de satisfactorio a moderado en el sur y el este. En este trabajo se analizan las causas de este episodio de alta contaminación. Aparte del efecto Diwali en la contaminación del aire, los hallazgos del estudio indicaron la importancia de la quema de biomasa sobre la India.
\end{abstract}

\begin{abstract}
Air pollution events have been a subject of major concern worldwide in recent years, since their frequency and intensity is increasing with time. An alarmingly high air pollution episode was observed in some parts of India during late October to the end of November in the year 2016. The Air Quality Index was observed to vary from poor to severe in northern and western parts of India, while it was satisfactory to moderate in the east and south of the country. The causes of this observed high pollution episode are examined in this paper. Apart from the Diwali effect on air pollution the study findings indicated the importance of biomass burning over India.
\end{abstract}

Keywords: Air pollution, transport, fireworks, biomass burning, Diwali.

\section{Introduction}

The adverse effects of atmospheric air pollution are currently well known (Tzanis et al., 2009, 2019; de la Fuente et al., 2011; Ganguly and Tzanis, 2011; Sinha et al., 2016; Fallahi et al., 2018). Air pollution occurs due to a number of factors such as interaction among local weather patterns, atmospheric circulation features, topography, human activities, emissions from vehicles, industries using coal for power, dust from construction activities and long-range transport of air pollutants (Rappengluck et al., 1999; Kossmann and Sturman, 2004; Mavrakou et al., 2012; Varotsos et al., 2012; Deligiorgi et al., 2013; Amanollahi et al., 2013, 2016; Alimissis et al., 2018). Large-scale airflows interact with mountain and valley winds to increase pollutant concentrations (Triantafyllou, 2001; Kitada and Regmi, 2003). Meteorological conditions also influence the chemical and physical processes involved in the formation of secondary pollutants (Nilsson et al., 2001a, b; Tzanis, 2005, $2009 \mathrm{a}, \mathrm{b})$. India is the seventh largest country in the world spanning between $8^{\circ} 4^{\prime}-37^{\circ} 6^{\prime} \mathrm{N}$ and $68^{\circ} 7^{\prime}-97^{\circ}$ 
$25^{\prime}$ E. It is also the world's second largest populated nation. Primary sources of air pollution in India include industries, power plants, biomass burning and vehicular transport. The growth in urban population and extensive development activities have further added to the increased levels of air pollution. The lack of an efficient public transport system in most cities and growing travel demands have fuelled the growth of private vehicles, thereby increasing pollutants concentrations. Particulate matter and $\mathrm{NO}_{\mathrm{x}}$ are the major pollutants that have been reported (Mahtta, 2015). An alarming increase in air pollution was observed in India during late October to the end of November in the year 2016. As the frequency and intensity of similar pollution events has increased in the recent years, the causes for this observed high pollution event are examined.

A possible cause of these high pollution levels could be the ignition of fireworks during the Diwali festival, which was celebrated on October 30, 2016 (Attri et al., 2001; Kulshrestha et al., 2004; Ganguly, 2009; Deka and Hoque, 2014; Saha et al., 2014; Ganguly, 2015). Another possible cause of the high pollution levels could be the burning of stubble in paddy fields in the states of Punjab, Haryana and Uttar Pradesh during the months of October and November (Mittal et al., 2009) to prepare the field for the next crop. It is an uncontrolled combustion process during which several tones of $\mathrm{CO}_{2}, \mathrm{NOx}$, $\mathrm{CH}_{4}, \mathrm{CO}, \mathrm{NH}_{3}, \mathrm{NMHC}, \mathrm{SO}_{2}$ and particulate matter are emitted (Streets et al., 2003; Gadde et al., 2009; Sahai et al., 2011; Jain et al., 2014). Finally, the high levels of pollution could also be due to long-distance transport of various air pollutants. The predominant cause for the observed pollution in different cities of India is examined in this study.

\section{Methods}

\subsection{Methodology}

The unique characteristics of the Diwali festival and its effects on air pollution levels over India require a nation-wide approach according to the following steps:

- Analysis of air pollution concentration levels for multiple air pollutants, using a representative air quality network in a countrywide level for two time frames (pre and during the Diwali festival).

- Association of air pollution levels and health impacts using indices (i.e., the Air Quality Index [AQI] - Table I).

- Analysis of the effects of principal factors that determine air pollution dispersion conditions, focusing on the effect of synoptic scale and local meteorological conditions.

- Assessment of the effect of additional air pollution sources. In the case of India during the Diwali festival the effect of uncontrolled combustion and long-range air pollution transport is evaluated.

\subsection{Area of study and data}

The case study is based on a nation-wide analysis of air pollution concentration levels due to the significant effect of the Diwali festival in every part of the country (Fig. 1).

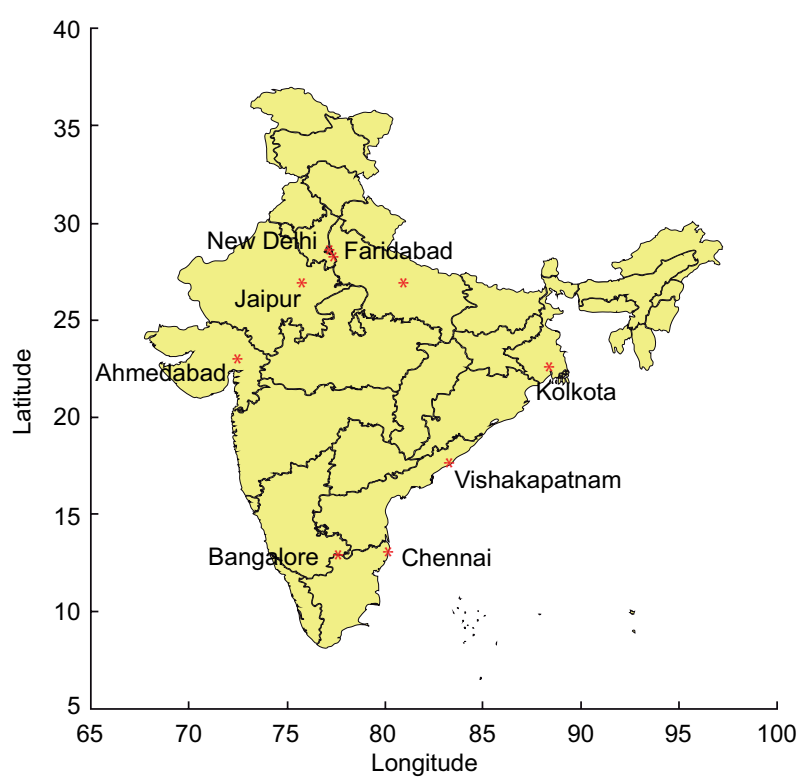

Fig. 1. India map and sites location.

The selected sites are presented in Table II along with the availability of air pollutant concentrations and wind speed data. In more detail, mean daily particulate matter $\left(\mathrm{PM}_{2.5}\right)$, sulfur dioxide $\left(\mathrm{SO}_{2}\right)$, ozone $\left(\mathrm{O}_{3}\right)$, nitrogen oxides $\left(\mathrm{NO}_{\mathrm{x}}\right)$, benzene $\left(\mathrm{C}_{6} \mathrm{H}_{6}\right)$ concentrations and wind speed and direction data are extracted from the database of the Indian Central Pollution Control Board (CPCB). According to the na- 
Table I. Air Quality Index categories and associated health impacts.

\begin{tabular}{|c|c|c|}
\hline AQI & & Health impacts. \\
\hline Good & $0-50$ & Minimal impact. \\
\hline Satisfactory & $51-100$ & May cause minor breathing discomfort to sensitive people. \\
\hline $\begin{array}{l}\text { Moderately } \\
\text { polluted }\end{array}$ & $101-200$ & $\begin{array}{l}\text { May cause breathing discomfort to people with lung disease such as asthma, and } \\
\text { discomfort to people with heart disease, children and older adults. }\end{array}$ \\
\hline Poor & $201-300$ & $\begin{array}{l}\text { May cause breathing discomfort to people on prolonged exposure, and discomfort to } \\
\text { people with heart disease. }\end{array}$ \\
\hline Ver poor & $301-400$ & $\begin{array}{l}\text { May cause respiratory illness to the people on prolonged exposure. Effect may be more } \\
\text { pronounced in people with lung and heart diseases. }\end{array}$ \\
\hline Severe & $401-500$ & $\begin{array}{l}\text { May cause respiratory effects even on healthy people and serious health impacts on } \\
\text { people with lung/heart diseases. The health impacts may be experienced even during } \\
\text { light physical activity. }\end{array}$ \\
\hline
\end{tabular}

tional ambient air quality standards, the permissible levels for $\mathrm{NO}_{\mathrm{x}}$ and $\mathrm{SO}_{2}$ concentrations are $80 \mu \mathrm{g} \mathrm{m}^{-3}$ for a 24-h average; $60 \mu \mathrm{g} \mathrm{m}^{-3}$ for $\mathrm{PM}_{2.5}, 100 \mu \mathrm{g} \mathrm{m}^{-3}$ for $\mathrm{O}_{3}$, and $2 \mu \mathrm{g} \mathrm{m}^{-3}$ of CO for an 8-h average; and $5 \mu \mathrm{g} \mathrm{m}^{-3}$ for $\mathrm{C}_{6} \mathrm{H}_{6}$ in an annual average.

Additionally to the above-mentioned ambient air pollutant concentrations, the daily AQI is also extracted from the CPCB database. The AQI in India is developed to inform the public about the exposure risk to air pollution and to help authorities to adopt effective air pollution control measures. The AQI system considers eight pollutants $\left(\mathrm{PM}_{10}, \mathrm{PM}_{2.5}, \mathrm{NO}_{2}\right.$, $\mathrm{SO}_{2}, \mathrm{CO}, \mathrm{O}_{3}, \mathrm{NH}_{3}$, and $\mathrm{Pb}$ ), calculates a sub-index for one of them and the overall AQI corresponds to the maximum value of the individual sub-indices. The proposed AQI index, based on the dose-response relationships for each pollutant, has six categories ranging from good to severe that relate to specific health impacts (Akolkar, 2014).

The effect of synoptic conditions is examined in terms of mean sea level pressure (MSLP), and the resulting wind field at $10 \mathrm{~m}$ is obtained from the NCEP/ NCAR Reanalysis I (Kalnay et al., 1996), whereas local wind conditions are extracted from the Indian Environment Network. The 5-day back trajectories at different altitudes have been retrieved from the HYSPLIT model of NOAAAir Resources Laboratory (Stein et al., 2015) based on Global Forecast System (GFS) meteorological data, while biomass burn- ing has been visualized from EOSDIS Worldview (https://earthdata.nasa.gov/labs/worldview).

\section{Results}

\subsection{Air quality assessment}

The AQI time series for the period under study and the selected sites over India are presented in figure 2. The overall air quality conditions over Faridabad, New Delhi and Lucknow range from very poor to severe (greater than 300 and 400, respectively) for significant number of days with important health implications even on healthy people. The conditions at Jaipur and Ahmedabad are considered poor or very poor for a small fraction of days whereas for the remaining sites (Kolkata, Chennai, Bangalore and Vishakapatnam) the conditions are considered healthier with very few days exceeding the 200 and 300 limits. It should be noted that the higher AQI values are associated with the sites located at the northern and western parts of India (Faridabad, New Delhi, Lucknow, Jaipur and Ahmedabad) and lower at the southern and eastern parts (Kolkata, Chennai, Vishakapatnam and Bangalore).

Regarding the mean daily $\mathrm{PM}_{2.5}, \mathrm{SO}_{2}, \mathrm{O}_{3}, \mathrm{CO}$, $\mathrm{NO}_{\mathrm{X}}$ and $\mathrm{C}_{6} \mathrm{H}_{6}$ concentrations for a normal day prior and post the Diwali festival (October 24 and November 5, 2016) and for the Diwali day (October 30, 2016), in Table III it is observed that in most cases 

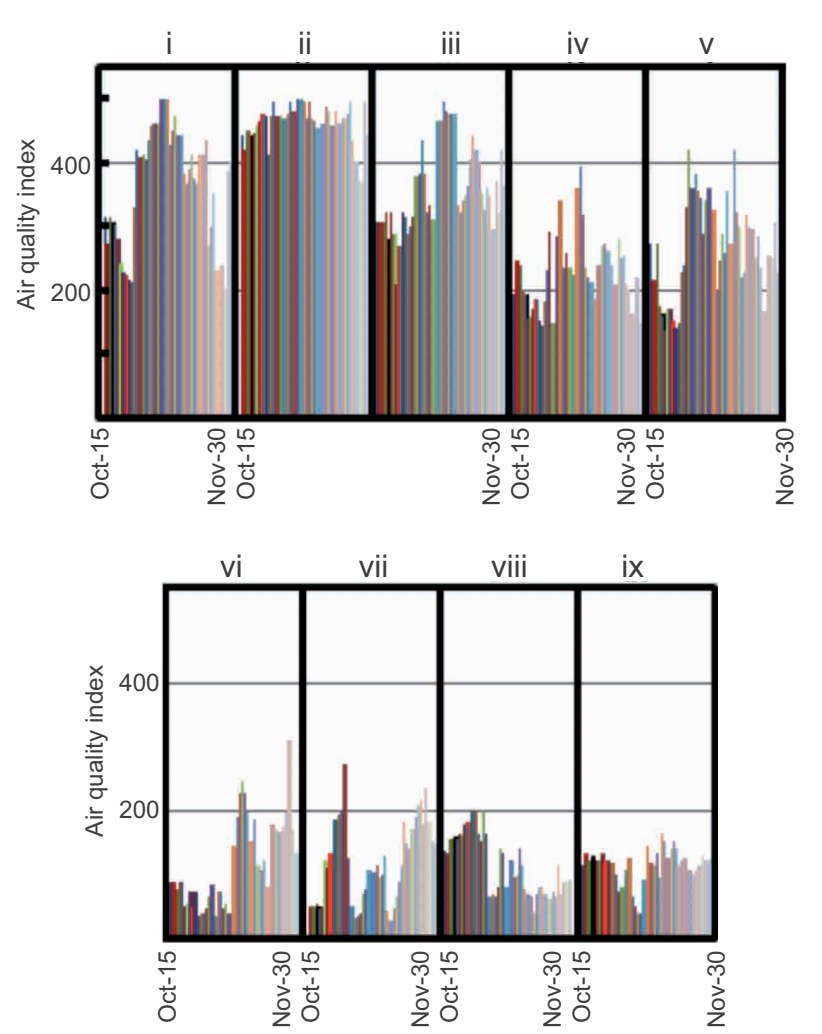

Fig. 2. Air Quality Index for the selected sites and period of study for Faridabad (i), New Delhi (ii), Lucknow (iii), Jaipuir (iv), Ahmedabad (v), Kolkota (vi), Chennai (vii), Bangalore (viii) and Vishakapatnam (ix).

for the Faridabad, New Delhi, Lucknow, Jaipur and Ahmedabad sites the concentrations during the Diwali day increased compared to normal days before and after Diwali. On the contrary, for the rest of the sites either minor increases or even decreases in air pollutant concentrations are observed.
Figure 3 shows the time series of air pollutant concentrations for the selected sites. A general remark is that, instead of subsiding after the Diwali festivities, pollution levels remained high from several days to about a month. In more detail, $\mathrm{PM}_{2.5}$ concentrations maxima are observed at the Ahmedabad site during the Diwali day $\left(1056 \mu \mathrm{g} \mathrm{m}^{-3}\right)$ and on November 14 and 23 (1183 and $883 \mu \mathrm{g} \mathrm{m}^{-3}$, respectively). High $\mathrm{PM}_{2.5}$ concentrations are also observed at the Faridabad, New Delhi and Jaipur sites from October 27 to mid-November. The $\mathrm{PM}_{2.5}$ pollution levels at the Vishakapatnam and Bangalore sites are considered normal with maximum values not exceeding $80 \mu \mathrm{g} \mathrm{m}^{-3}$ during the entire period of study. Regarding $\mathrm{SO}_{2}$ concentration levels, the maximum values are also reported at the Faridabad site prior and after the Diwali festival and at the New Delhi site from October 29-31. High levels of $\mathrm{O}_{3}$ concentrations are observed only at the Ahmedabad site from the Diwali day to November 22 , while its maximum value $\left(235 \mu \mathrm{g} \mathrm{m}^{-3}\right)$ is observed on November 15 . For the remaining sites, concentration levels were below the $100 \mu \mathrm{g} \mathrm{m}^{-3}$ permissible level during the majority of days. Maximum $\mathrm{CO}$ concentrations were observed at Jaipur $\left(8.39 \mu \mathrm{g} \mathrm{m}^{-3}\right)$ on the October 29, whereas high pollution levels were observed in New Delhi throughout the study period. Furthermore, high $\mathrm{CO}$ concentrations were reported on October 17 and 19 at the Kolkata site (6.24 and $8.06 \mu \mathrm{g} \mathrm{m}^{-3}$, respectively) from October 25 to November 23 at Ahmedabad, between October 17 to November 30 at Faridabad, and about November 15 at Lucknow. For the remaining sites (Chennai, Vishakapatnam and Bangalore), $\mathrm{CO}$ concentrations were below the $2 \mu \mathrm{g} \mathrm{m}^{-3}$ level. The $\mathrm{NO}_{\mathrm{X}}$ pollution

Table II. Air monitoring stations and availability of air quality and wind data.

\begin{tabular}{llccccccc}
\hline City & State & $\mathrm{PM}_{2.5}$ & $\mathrm{SO}_{2}$ & $\mathrm{O}_{3}$ & $\mathrm{CO}$ & $\mathrm{NO}_{\mathrm{X}}$ & $\mathrm{C}_{6} \mathrm{H}_{6}$ & WS \\
\hline Faridabad & Haryana & $\checkmark$ & $\checkmark$ & $\checkmark$ & $\checkmark$ & $\checkmark$ & $\checkmark$ & $\checkmark$ \\
New Delhi & Delhi & $\checkmark$ & $\checkmark$ & $\checkmark$ & $\checkmark$ & $\checkmark$ & $\checkmark$ & $\checkmark$ \\
Lucknow & Uttar Pradesh & $\checkmark$ & $\checkmark$ & $\checkmark$ & $\checkmark$ & $\checkmark$ & $\checkmark$ & $\checkmark$ \\
Jaipur & Rajasthan & $\checkmark$ & $\checkmark$ & $\checkmark$ & $\checkmark$ & $\checkmark$ & $\checkmark$ & $\checkmark$ \\
Ahmedabad & Gujarat & $\checkmark$ & $\checkmark$ & $\checkmark$ & $\checkmark$ & $\checkmark$ & $\checkmark$ & $\checkmark$ \\
Kolkata & West Bengal & $x$ & $x$ & $\checkmark$ & $\checkmark$ & $\checkmark$ & $x$ & $x$ \\
Chennai & Tamilnadu & $\checkmark$ & $\checkmark$ & $\checkmark$ & $\checkmark$ & $\checkmark$ & $\checkmark$ & $x$ \\
Bangalore & Karnataka & $\checkmark$ & $\checkmark$ & $\checkmark$ & $\checkmark$ & $\checkmark$ & $\checkmark$ & $x$ \\
Vishakapatnam & Andhra Pradesh & $\checkmark$ & $\checkmark$ & $\checkmark$ & $\checkmark$ & $\checkmark$ & $\checkmark$ & $x$ \\
\hline
\end{tabular}



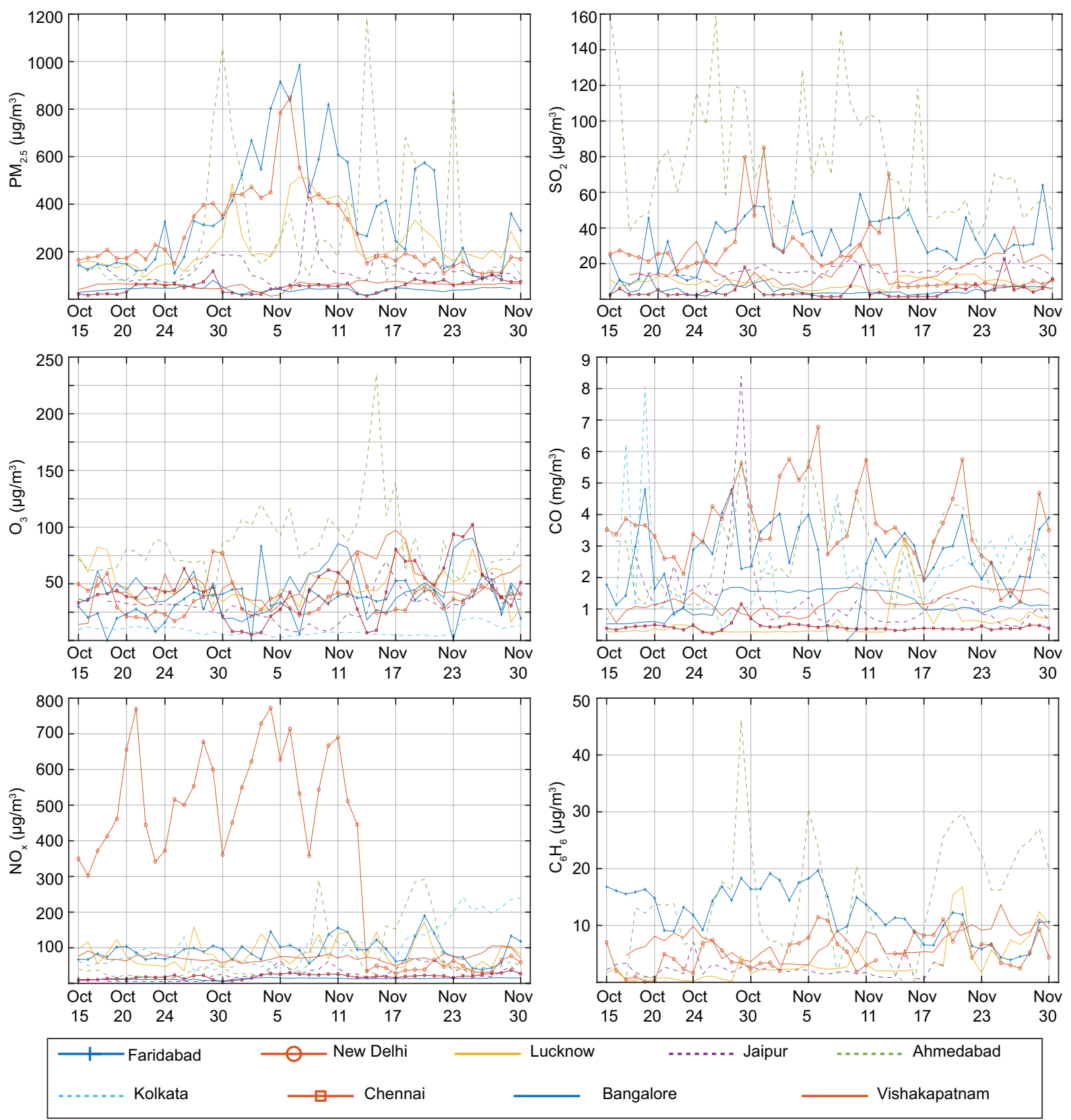

Fig. 3. Time series of air pollutant concentrations from October 15 to November 30, 2016 (pre-Diwali [October 24], Diwali [October 30] and post-Diwali [November 5]).

levels exhibit significant differences between the New Delhi site and the remaining stations. Between October 15 to November $13, \mathrm{NO}_{\mathrm{X}}$ values ranged from 302 to $773 \mu \mathrm{g} \mathrm{m}^{-3}$. High $\mathrm{NO}_{\mathrm{X}}$ concentrations were also observed on November 9 and between November 16 to 21 at Ahmedabad; in the Kolkata site, an increasing trend is observed after November
18. $\mathrm{NO}_{\mathrm{X}}$ concentrations were below the $80 \mu \mathrm{g} \mathrm{m}^{-3}$ level at the Jaipur, Chennai and Bangalore sites. Regarding $\mathrm{C}_{6} \mathrm{H}_{6}$ concentrations, the highest pollution levels were observed at the Ahmedabad site between October 18 and November 30, with a maximum value of $46 \mu \mathrm{g} \mathrm{m}^{-3}$. Days with higher than $100 \mu \mathrm{g} \mathrm{m}^{-3}$ were also observed at the Faridabad, Lucknow, New Delhi 
and Vishakapatnam sites, which may be attributed to emissions from vehicles and from coal combustion industries for power generation (Mahtta, 2015).

The above findings indicate that firework emissions during the Diwali festival are not the primary cause of pollution, but they might have added to already existing polluting sources. It should be noted that, compared to previous years, in 2016 fewer firecrackers were ignited due to a government ban on firecrackers to control noise and air pollution. There was no increase in sound levels, but the levels of atmospheric pollutants $\left(\mathrm{CO}, \mathrm{NOx}, \mathrm{O}_{3}, \mathrm{C}_{6} \mathrm{H}_{6}, \mathrm{SO}_{2}\right.$ and $\mathrm{PM}_{2.5}$ ) increased significantly in the states of Haryana, Uttar Pradesh and Delhi (in northern India), and at Rajasthan and Gujarat (in western India).

Under this assumption, the effect of emissions from biomass burning is also examined. The fire events during October and November are evident in the EOSDIS Worldview images (Fig. 4). Intense active fires (marked with red dots) associated with the burning of agricultural crop residues over Punjab, Haryana, Uttar Pradesh and New Delhi in north India, as well as the scattered occurrence of fires over Rajasthan and Gujarat in west India, and West Bengal in east India are easily identified, validating the importance of biomass burning emissions. The AQI results are consistent with findings of the biomass burning fire events, highlighting their importance in the increased levels of pollution over specific areas of India. Other studies have also identified the effect of crop residues burning fires in north India during October and November (Mittal et al., 2009). This indicates that the high levels of $\mathrm{CO}, \mathrm{NO}_{\mathrm{X}}, \mathrm{SO}_{2}$ and particulate matter can also be attributed to the burning of agriculture crop residues, in addition to the Diwali festival and other local sources such as vehicle emissions, coal burning power generation, and dust emissions from construction activities.
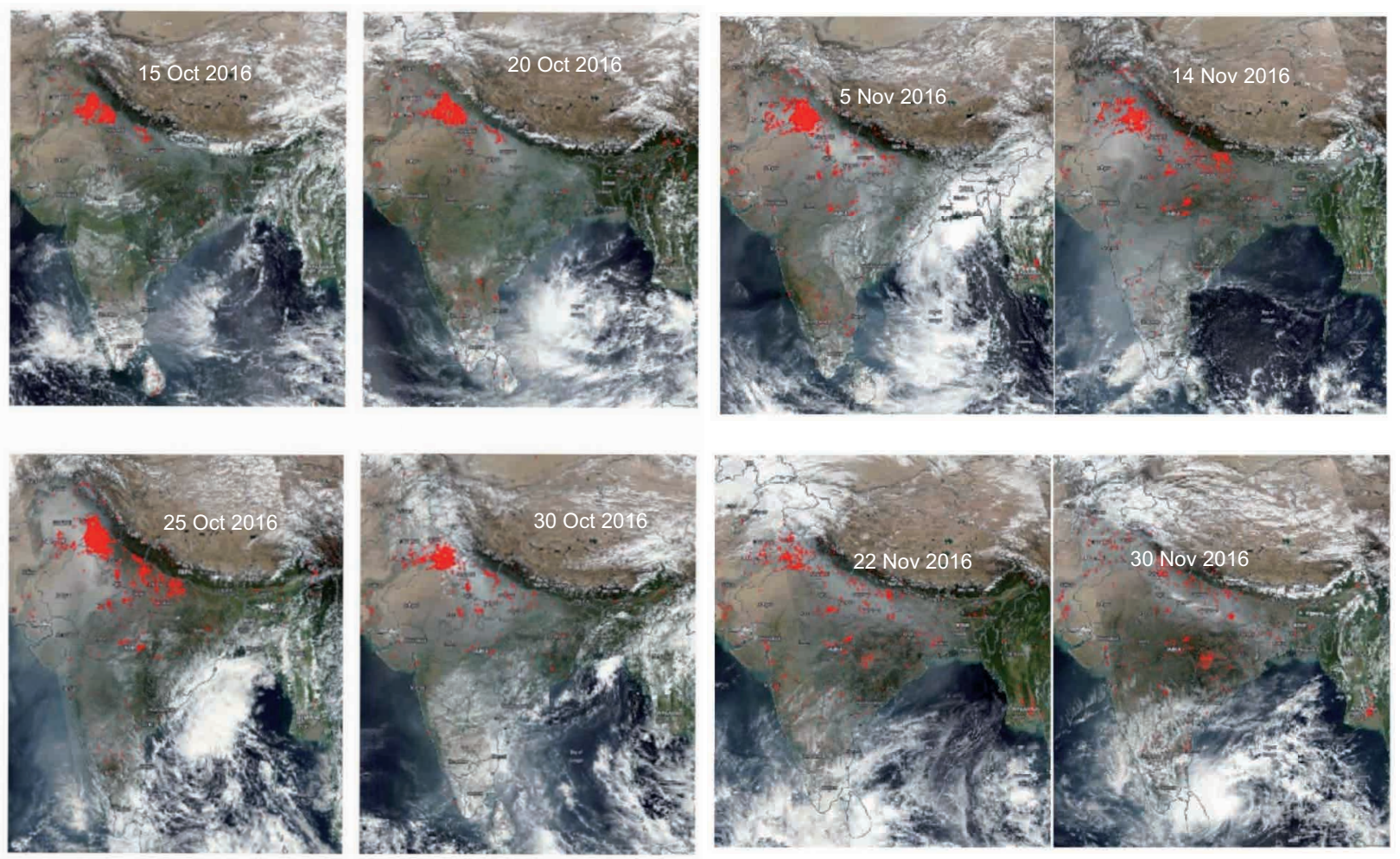

Fig. 4. Intense active fires (marked with red dots) associated with the burning of agricultural crop residues over Punjab, Haryana, Uttar Pradesh and New Delhi in north India, as well as scattered occurrence of fires over Rajasthan, Gujarat in west India, and West Bengal in east India, during October-November 2016. 
3.2. Meteorological conditions and long- range transport of air pollution

The synoptic conditions and the resulting surface wind field are considered the most important factor in the conditions for air pollution dispersion. The daily MSLP, along with the wind field over India are examined for the entire period of study and visualized in figure 5 during the Diwali festival and for two rep- resentative normal days prior and after the festival (a normal day is a day where pollutant concentrations have the same air pollution levels as the average of a 10-day period prior and after the Diwali day). As it can be observed, unfavorable dispersion conditions prevail over India during the Diwali festival, as a result of a smooth pressure field. Higher wind speed values are only observed at the southern part of the
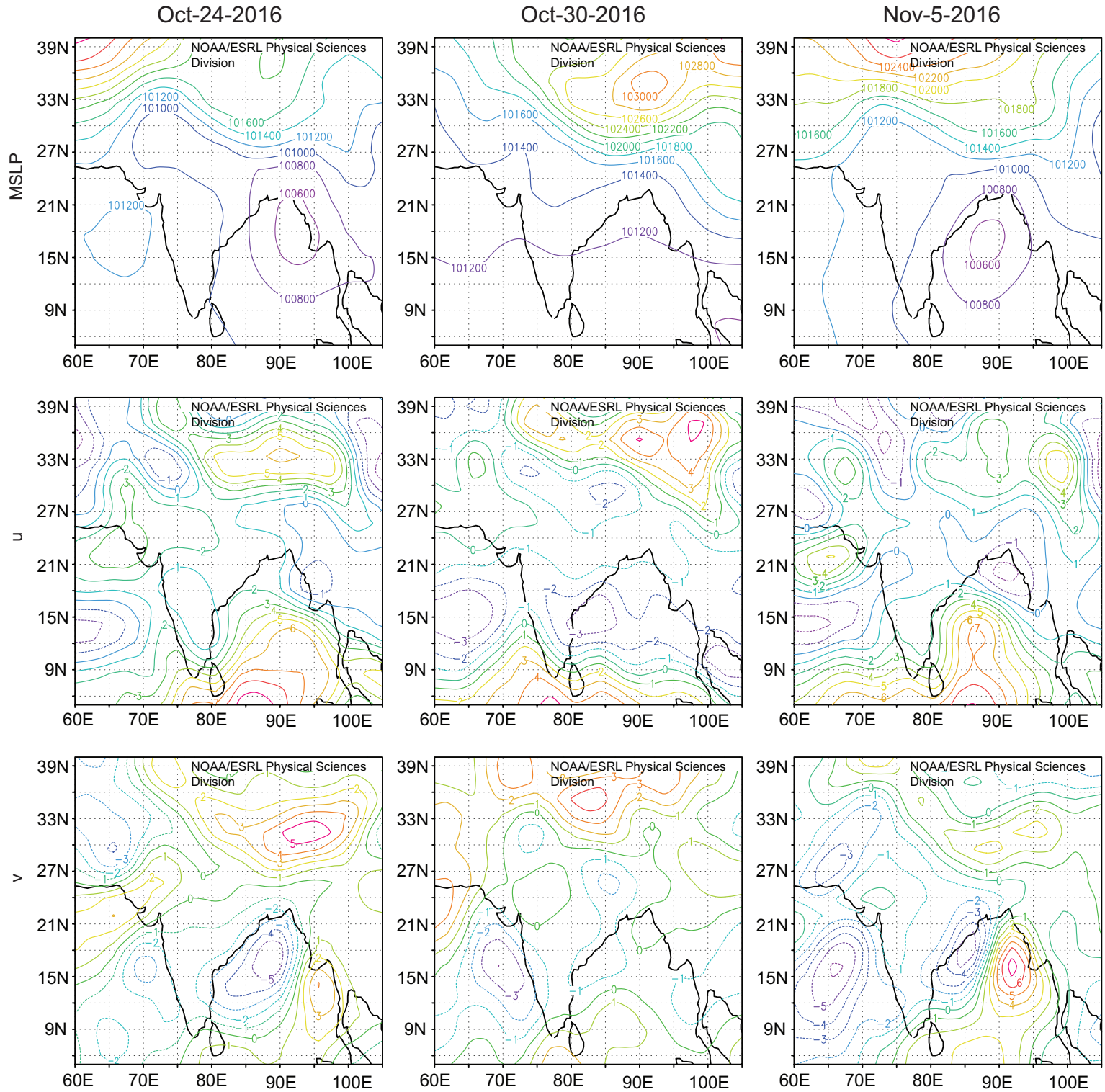

Fig. 5. Synoptic conditions and associated wind field in terms of MSLP, $u$ and $v$ wind components at $10 \mathrm{~m}$ over India during the Diwali festival (October 30, 2016), and before and after Diwali (October 24 and November 5,2016 , respectively). 


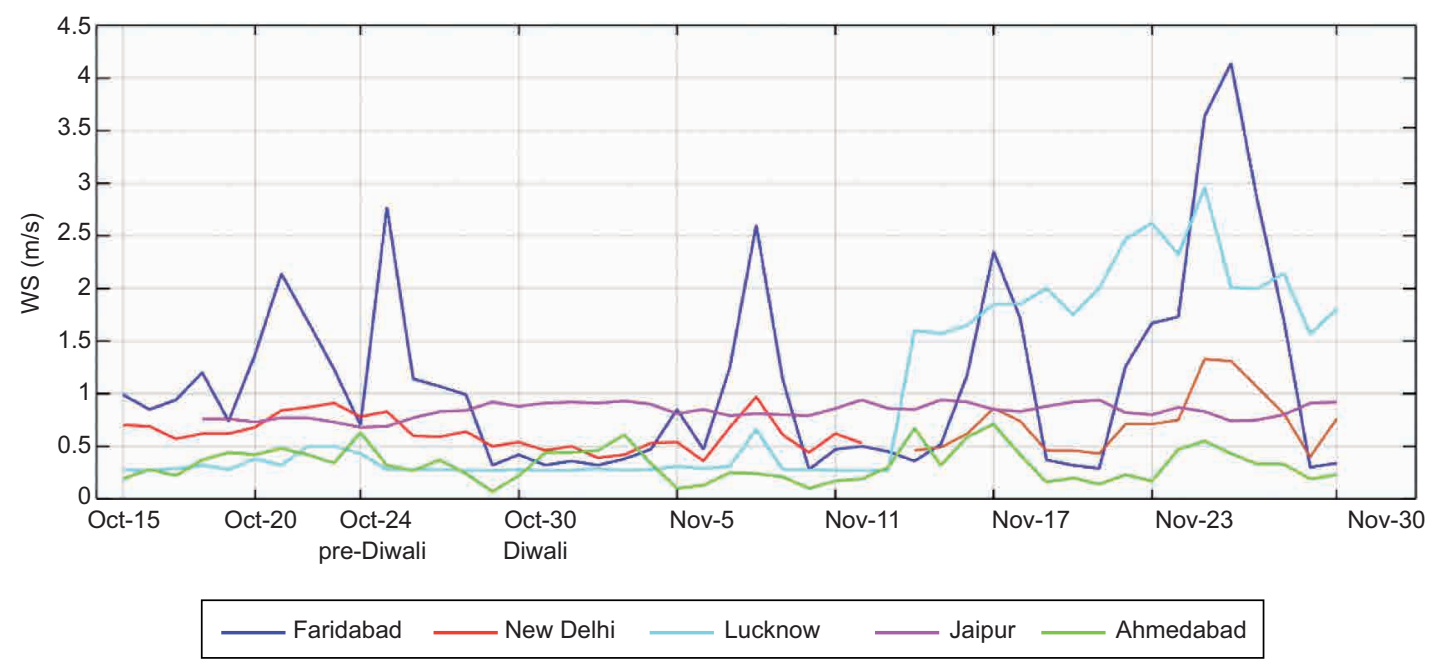

Fig. 6. Wind time series for New Delhi, Jaipur, Ahmedabad, and Chennai sites during the study period.

Indian peninsula with an easterly direction. During normal days, a low-pressure center is located at the Bengal Bay leading to better dispersion conditions at the southern and eastern parts of India, and to stagnation of pollutants and higher resulting pollution levels at the northern and eastern parts.

Wind time series for the New Delhi, Jaipur, Ahmedabad, and Chennai sites are presented in figure 6. Figure 7 presents the NOAA HYSPLIT derived five-day back trajectories ending at the Indian cities of Faridabad, New Delhi, Lucknow, Jaipur, Ahmedabad, Kolkata and Vishakapatnam at three altitudes $(0,500$ and $1000 \mathrm{~m})$ at 12:00 UTC on October 27 and November 7, 2016. The back trajectories indicate transport from the north, north-west and west at Faridabad, New Delhi, Lucknow, Jaipur, Ahmedabad, Kolkata and Vishakapatnam during the study period at three altitudes. Low wind speed values are denoted for each experimental site. The above findings are also in accordance with the assumption that high pollution levels of $\mathrm{AQI}, \mathrm{CO}, \mathrm{NO}_{\mathrm{X}}, \mathrm{SO}_{2}$ and $\mathrm{PM}$ over northern, western and eastern India may be attributed to the transport of polluted air associated with the burning of agriculture crop residues in the states of Punjab, Haryana and Uttar Pradesh. Badarinath et al. (2009a, b) also present similar findings. These authors state that aerosols/trace gases from regions where agriculture crop residues are burnt, are transported to the urban regions of Hyderabad and the Arabian Sea.

\section{Conclusions}

The predominant cause for the sudden degradation of ambient air quality in the year 2016 at Faridabad and Lucknow was biomass burning emissions in Uttar Pradesh, Punjab and Haryana. Long range transport of this polluted air led to the deterioration of air quality in Ahmedabad, New Delhi, Jaipur and Kolkata (with approximately 35 million inhabitants). Ignition of fireworks, emissions from vehicles, industries using coal for power and dust from construction activities have further added to the existing pollution. Low wind speed at Ahmedabad and New Delhi might have caused lower dispersive capacity in the atmosphere, leading to stagnation of these pollutants. Future work will be focused on numerical modeling for supporting the observational findings.

\section{Acknowledgments}

The Air Quality Index, concentration of gaseous pollutants and meteorological parameters for Indian cities was obtained from the website of the Central Pollution Control Board (CPCB). The 5-day back trajectories at different altitudes have been retrieved 
Faridabad (Haryana)
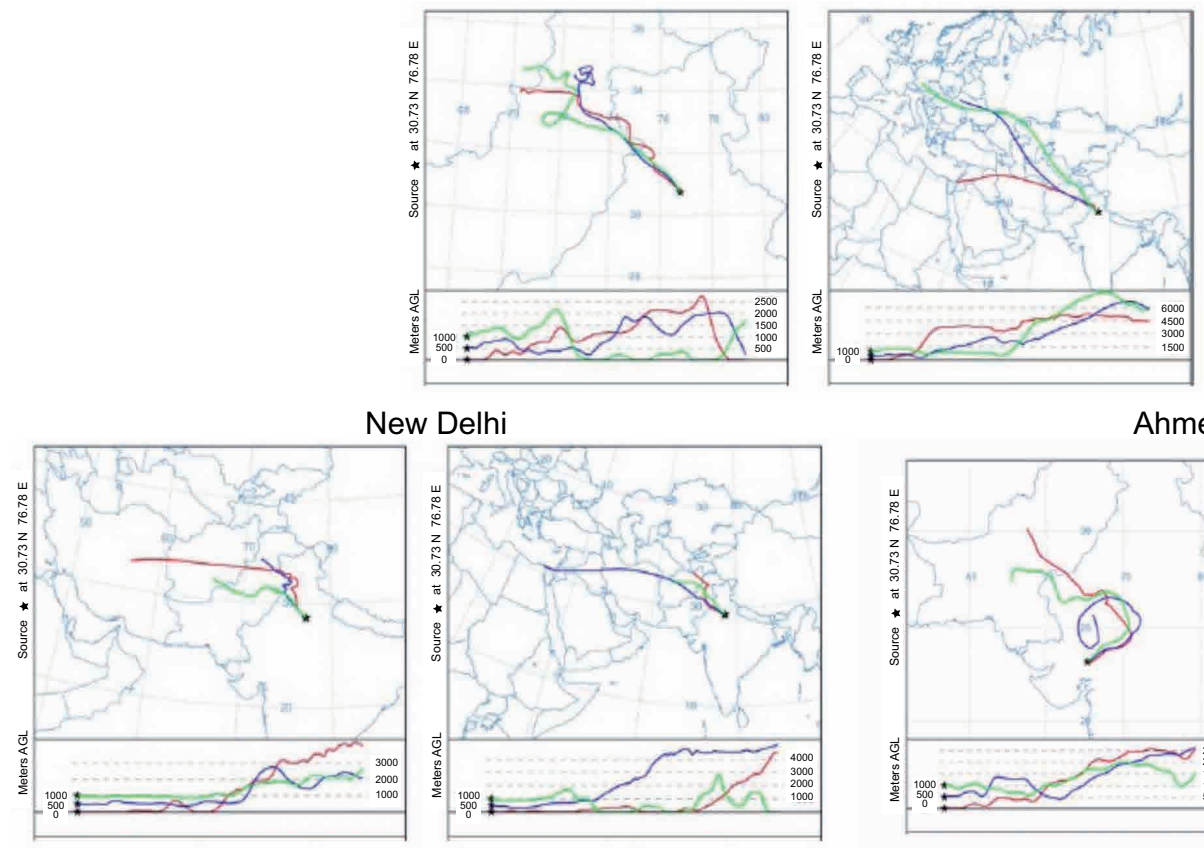

Lucknow (Uttar Pradesh)
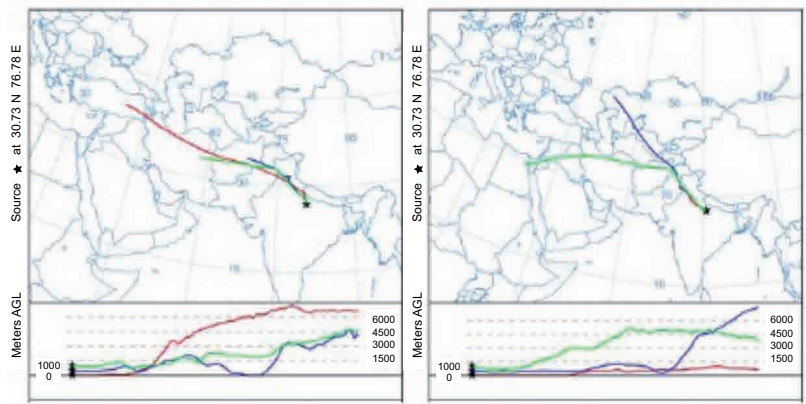

Jaipur (Rajasthan)
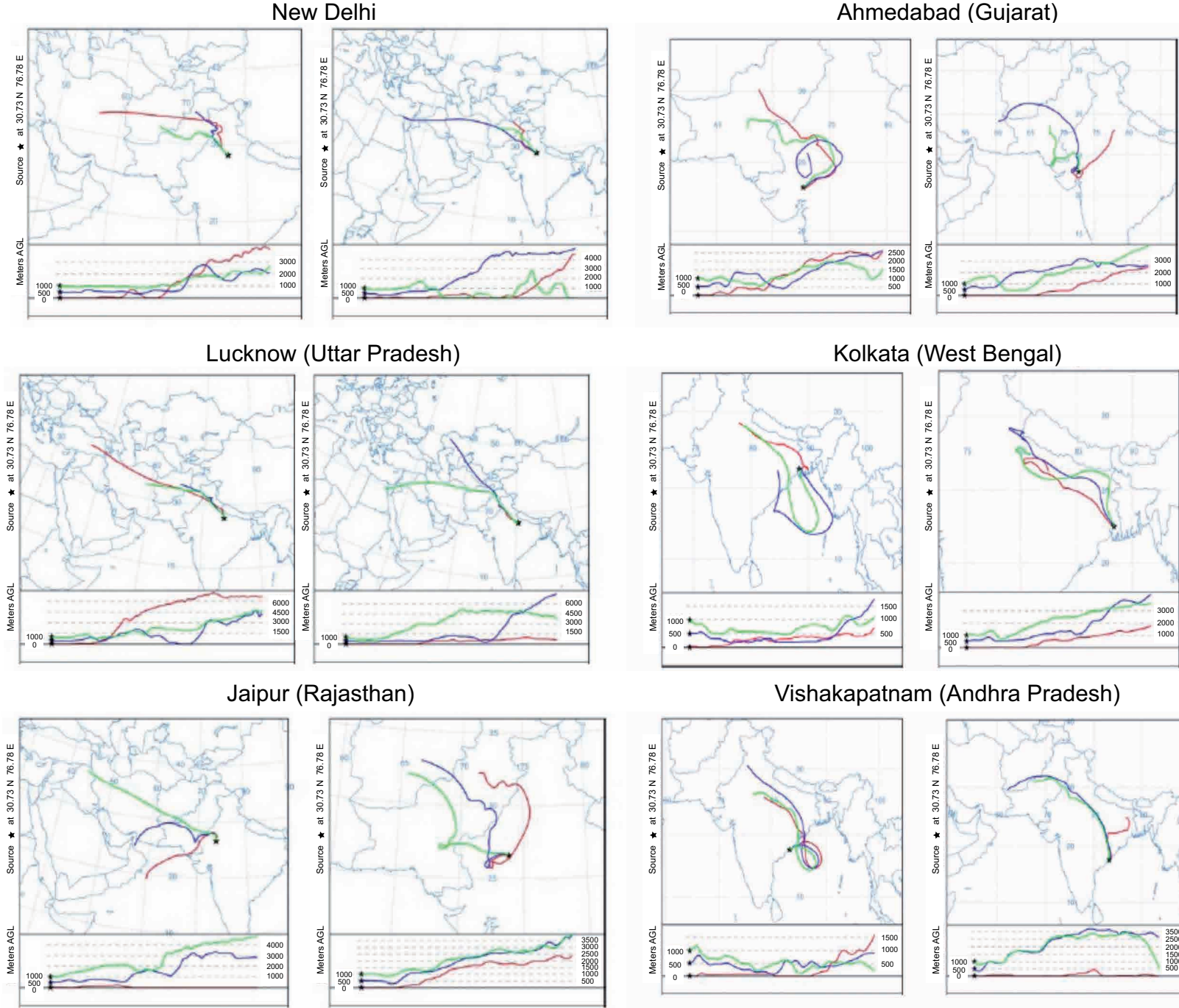

Kolkata (West Bengal)
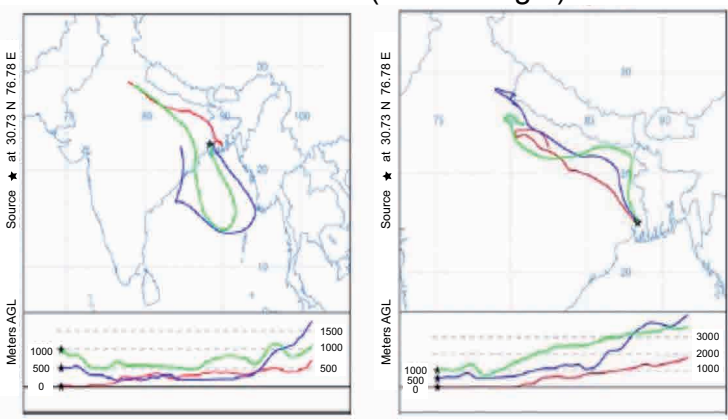

Vishakapatnam (Andhra Pradesh)
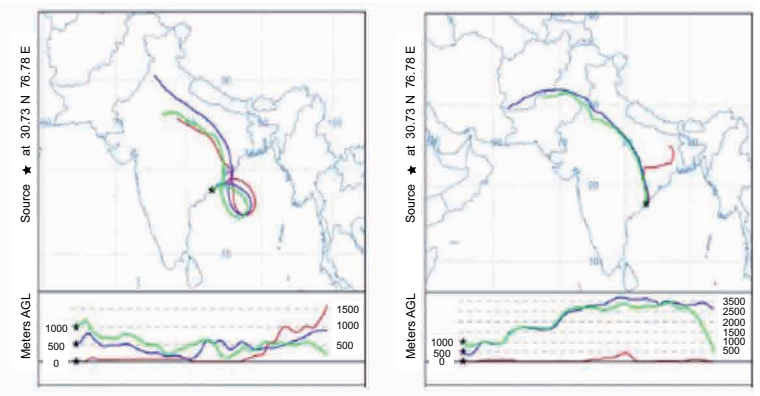

Fig. 7. NOAA HYSPLIT derived 5-day back trajectories ending at Indian cities Faridabad (Haryana), New Delhi and Lucknow (Uttar Pradesh), Jaipur (Rajasthan), Ahmedabad (Gujarat), Kolkata (West Bengal), and Vishakapatnam (Andhra Pradesh) at three altitudes (0,500 and $1000 \mathrm{~m})$ at 12:00 UTC on October 27 and November 7, 2016. 
Table III. Comparison of normal days pre and post-Diwali to Diwali day air pollutant concentrations.

\begin{tabular}{|c|c|c|c|c|c|c|c|}
\hline & & $\mathrm{PM}_{2.5}$ & $\mathrm{SO}_{2}$ & $\mathrm{O}_{3}$ & $\mathrm{CO}$ & $\mathrm{NO}_{\mathrm{X}}$ & $\mathrm{C}_{6} \mathrm{H}_{6}$ \\
\hline \multirow[t]{3}{*}{ Faridabad } & Pre-Diwali & 326.05 & 12.38 & 16.02 & 2.88 & 68.05 & 11.84 \\
\hline & Diwali & 338.86 & 52.34 & 40.91 & 2.35 & 96.21 & 16.38 \\
\hline & Post-Diwali & 915.15 & 38.28 & 33.31 & 4 & 101.66 & 18.26 \\
\hline \multirow[t]{3}{*}{ New Delhi } & Pre-Diwali & 209.37 & 20.51 & 23.13 & 3.38 & 372.42 & 1.63 \\
\hline & Diwali & 350.21 & 46.97 & 77.07 & 4.25 & 361.11 & 2.42 \\
\hline & Post-Diwali & 783.31 & 23.36 & 39.8 & 5.52 & 627.72 & 7.86 \\
\hline \multirow[t]{3}{*}{ Lucknow } & Pre-Diwali & 149.18 & 8.21 & 45 & 0.43 & 46.78 & 0.19 \\
\hline & Diwali & 270.39 & 9.6 & 34.16 & 0.28 & 48.25 & 1.51 \\
\hline & Post-Diwali & 248.27 & 4.7 & 45.65 & 0.31 & 74.82 & 3.1 \\
\hline \multirow[t]{3}{*}{ Jaipur } & Pre-Diwali & 71.42 & 12.09 & 31.77 & 1.63 & 5.39 & 7.1 \\
\hline & Diwali & 185.56 & 16.95 & 23.86 & 2.6 & 25.48 & 2.95 \\
\hline & Post-Diwali & 39.77 & 15.65 & 11.66 & 1.37 & 62.83 & 2.07 \\
\hline \multirow[t]{3}{*}{ Ahmedabad } & Pre-Diwali & 74.22 & 115.96 & 86.66 & 1.13 & 15.7 & 7 \\
\hline & Diwali & 1055.72 & 66.88 & 87.76 & 4.24 & 44.49 & 24.67 \\
\hline & Post-Diwali & 260.27 & 68.01 & 92.1 & 5.82 & 55.28 & 30.48 \\
\hline \multirow[t]{3}{*}{ Kolkata } & Pre-Diwali & NA & NA & 11.64 & 0.93 & 80.02 & NA \\
\hline & Diwali & NA & NA & 5.38 & 1.12 & 45.74 & NA \\
\hline & Post-Diwali & NA & NA & 2.7 & NA & 28.48 & NA \\
\hline \multirow[t]{3}{*}{ Chennai } & Pre-Diwali & 56.71 & 2.21 & 42.59 & 0.49 & 17.77 & NA \\
\hline & Diwali & 30.7 & 7.08 & 21.42 & 0.7 & 5.54 & NA \\
\hline & Post-Diwali & 46.61 & 2.36 & 27.45 & 0.47 & 25.71 & NA \\
\hline \multirow[t]{3}{*}{ Bangalore } & Pre-Diwali & 46.77 & 2.37 & 34.72 & 0.81 & 11.12 & NA \\
\hline & Diwali & 52.35 & 9.1 & 19.08 & 1.56 & 6.07 & NA \\
\hline & Post-Diwali & 41.17 & 3.07 & 38.58 & 1.54 & 15.64 & NA \\
\hline \multirow[t]{3}{*}{ Vishakapatnam } & Pre-Diwali & 63.19 & 32.65 & 58.71 & 1.54 & 77.2 & 9.85 \\
\hline & Diwali & 45.56 & 15.19 & 46.06 & 0.77 & 57.94 & 3.65 \\
\hline & Post-Diwali & 19.17 & 8.71 & 31.98 & 0.75 & 75.46 & 3.08 \\
\hline
\end{tabular}

Values in bold type: lower Diwali day air pollutant concentrations; NA: not available data.

from the HYSPLIT transport and dispersion model of NOAAAir Resources Laboratory (ARL). Biomass burning has been visualized from NASA EOSDIS Worldview.

\section{References}

Akolkar AB. 2014. National Air Quality Index. Central Pollution Control Board, Ministry of Environment, Forests and Climate Change, India.

Alimissis A, Philippopoulos K, Tzanis CG, Deligiorgi D. 2018. Spatial estimation of urban air pollution with the use of artificial neural network models. Atmospheric
Environment 191:205-213.

DOI: 10.1016/j.atmosenv.2018.07.058

Amanollahi J, Tzanis C, Abdullah AM, Ramli MF, Pirasteh S. 2013. Development of the models to estimate particulate matter from thermal infrared band of Landsat Enhanced Thematic Mapper. International Journal of Environmental Science and Technology 10:1245-1254.

DOI: $10.1007 / \mathrm{s} 13762-012-0150-7$

Amanollahi J, Tzanis C, Ramli MF, Abdullah AM. 2016. Urban heat evolution in a tropical area utilizing Landsat imagery. Atmospheric Research 167:175-182.

DOI: 10.1016/j.atmosres.2015.07.019 
Attri AK, Kumar U, Jain VK. 2001. Formation of ozone by fireworks. Nature 411:1015. DOI: 10.1038/35082634

Badarinath KVS, Kumar KS, Sharma AR. 2009a. Longrange transport of aerosols from agriculture crop residue burning in Indo-Gangetic Plains - A study using LIDAR, ground measurements and satellite data. Journal of Atmospheric and Solar-Terrestrial Physics 71:112-120. DOI: 10.1016/j.jastp.2008.09.035

Badarinath KVS, Kharol SK, Sharma AR, Krishna PV. 2009b. Analysis of aerosol and carbon monoxide characteristics over Arabian Sea during crop residue burning period in the Indo-Gangetic Plains using multi-satellite remote sensing datasets. Journal of Atmospheric and Solar-Terrestrial Physics 71:12671276. DOI: 10.1016/j.jastp.2009.04.004

De la Fuente D, Vega JM, Viejo F, Díaz I, Morcillo M. 2011. City scale assessment model for air pollution effects on the cultural heritage. Atmospheric Environment 45:1242-1250. DOI: 10.1016/j.atmosenv.2010.12.011

Deligiorgi, D, Philippopoulos K, Karvounis G. 2013. Estimation of pollution dispersion patterns of a power plant plume in complex terrain. Global NEST Journal 15:227-240. DOI: 10.30955/gnj.000955

Deka P, Hoque RR. 2014. Incremental effect of festive biomass burning on wintertime $\mathrm{PM}_{10}$ in Brahmaputra Valley of Northeast India. Atmospheric Research 143:380-391.

DOI: 10.1016/j.atmosres.2014.03.003

Fallahi S, Amanollahi J, Tzanis CG, Ramli MF. 2018. Estimating solar radiation using NOAA/AVHRR and ground measurement data. Atmospheric Research 199:93-102. DOI: 10.1016/j.atmosres.2017.09.006

Gadde B., Bonnet S, Menke C, Garivait S. 2009. Air pollutant emissions from rice straw open field burning in India, Thailand and the Philippines. Environmental Pollution 157:1554-1558.

DOI: 10.1016/j.envpol.2009.01.004

Ganguly ND. 2009. Surface ozone pollution during the festival of Diwali, New Delhi, India Earth Science India 2:224-229.

Ganguly ND, Tzanis C. 2011. Study of stratosphere-troposphere exchange events of ozone in India and Greece using ozonesonde ascents. Meteorological Applications 18:467-474. DOI: 10.1002/met.241

Ganguly ND. 2015. Short term change in relative humidity during the festival of Diwali in India. Journal of Atmospheric and Solar-Terrestrial Physics 129:49-54. DOI: 10.1016/j.jastp.2015.04.007
Jain N, Bhatia A, Pathak H. 2014. Emission of air pollutants from crop residue burning in India. Aerosol and Air Quality Research 14:422-430.

DOI: 10.4209/aaqr.2013.01.0031

Kalnay E, Kanamitsu M, Kistler R, Collins W, Deaven D, Gandin L, Iredell M, Saha S, White G, Woollen J, Zhu Y, Chelliah M, Ebisuzaki W, Higgins W, Janowiak J, Mo KC, Ropelewski C, Wang J, Leetmaa A, Reynolds R, Jenne R, Joseph D 1996. The NCEP/NCAR 40-year reanalysis project. Bulletin of the American Meteorological Society 77:437-471.

DOI: 10.1175/1520-0477(1996)077\%3C0437:TNYRP\%3E2.0.CO;2

Kitada T, Regmi RP. 2003. Dynamics of air pollution transport in late wintertime over Kathmandu valley, Nepal, as revealed with numerical simulation. Journal of Applied Meteorology and Climatology 12:1770-1798. DOI: 10.1175/1520-0450(2003)042\%3C1770:DOAPTI\%3E2.0.CO;2

Kossmann M, Sturman A. 2004. The surface wind field during winter smog nights in Christchurch and coastal Canterbury, New Zealand. International Journal of Climatology 24:93-108. DOI: 10.1002/joc.981

Kulshrestha UC, Nageswara RT, Azhaguvel S Kulshrestha MJ. 2004. Emissions and accumulation of metals in the atmosphere due to crackers and sparkles during Diwali festival in India. Atmospheric Environment 38:4421-4425. DOI: 10.1016/j.atmosenv.2004.05.044

Mahtta R. 2015. Green growth and air pollution in India. The Energy and Resources Institute (TERI), New Delhi, 18 pp.

Mavrakou T, Philippopoulos K, Deligiorgi D. 2012. The impact of sea breeze under different synoptic patterns on air pollution within Athens basin. Science of the Total Environment 433: 31-43.

DOI: 10.1016/j.scitotenv.2012.06.011

Mittal SK, Singh N, Agarwal R, Awasthi A Gupta PK. 2009. Ambient air quality during wheat and rice crop stubble burning episodes in Patiala. Atmospheric Environment 43:238-244. DOI: 10.1016/j.atmosenv.2008.09.068

Nilsson ED, Paatero J, Boy M. 2001a. Effects of air masses and synoptic weather on aerosol formation in the continental boundary layer. Tellus B: Chemical and Physical Meteorology 53:462-478.

DOI: 10.3402/tellusb.v53i4.16619

Nilsson ED, Rannik U, Kulmala M, Buzorius G, O’Dowd CD. 2001b. Effects of continental boundary layer evolution, convection, turbulence and entrainment, on 
aerosol formation. Tellus B: Chemical and Physical Meteorology 53:441-461.

DOI: 10.3402/tellusb.v53i4.16617

Rappengluck B, Oyola P, Olaeta I, Fabian P. 1999. The evolution of photochemical smog in the metropolitan area of Santiago de Chile. Journal of Applied Meteorology 39:275-290.

DOI: 10.1175/1520-0450(2000)039\%3C0275:TEOPSI\%3E2.0.CO;2.

Saha U, Talukdar S, Jana S, Maitra A. 2014. Effects of air pollution on meteorological parameters during Deepawali festival over an Indian urban metropolis. Atmospheric Environment 98:530-539.

DOI: 10.1016/j.atmosenv.2014.09.032

Sahai S, Sharma C, Singh SK, Gupta PK. 2011. Assessment of trace gases, carbon and nitrogen emissions from field burning of agricultural residues in India. Nutrient Cycling in Agroecosystems 89:143-157. DOI: 10.1007/s10705-010-9384-2

Sinha PR, Sahu LK, Manchanda RK, Sheel V, Deushi M, Kajino M, Schultz MG, Nagendra N, Kumar P, Trivedi DB, Koli SK, Peshin SK, Swamy YV, Tzanis CG, Sreenivasan S. 2016. Transport of tropospheric and stratospheric ozone over India: Balloon-borne observations and modeling analysis. Atmospheric Environment 131:228-242. DOI: 10.1016/j.atmosenv.2016.02.001

Stein AF, Draxler RR, Rolph GD, Stunder BJB, Cohen MD, Ngan F. 2015. NOAA's HYSPLIT atmospheric transport and dispersion modeling system. Bulletin of the American Meteorological Society 96:2059-2077. DOI: 10.1175/BAMS-D-14-00110.1

Streets DG, Yarber KF, Woo JH, Carmichae GR. 2003. Biomass burning in Asia: Annual and seasonal esti- mates and atmospheric emissions. Global Biogeochemical Cycles 17:1099, doi: 10.1029/2003GB002040

Triantafyllou AG. 2001. PM10 pollution episodes as a function of synoptic climatology in a mountainous industrial area. Environmental Pollution 112:491-500. DOI: $10.1016 / \mathrm{S} 0269-7491(00) 00131-7$

Tzanis C. 2005. Ground-based observations of ozone at Athens, Greece during the solar eclipse of 1999. International Journal of Remote Sensing 26:3585-3596. DOI: 10.1080/01431160500076947

Tzanis C. 2009a. On the relationship between total ozone and temperature in the troposphere and the lower stratosphere. International Journal of Remote Sensing 30:6075-6084. DOI: 10.1080/01431160902798429

Tzanis C. 2009b. Total ozone observations at Athens, Greece by satellite-borne and ground-based instrumentation. International Journal of Remote Sensing 30:6023-6033.

DOI: $10.1080 / 01431160902798411$

Tzanis C, Tsivola E, Efstathiou M, Varotsos C, 2009. Forest fires pollution impact on the solar UV irradiance at the ground. Fresenius Environmental Bulletin 18:2151-2158.

Tzanis CG, Alimissis A, Philippopoulos K, Deligiorgi D. 2019. Applying linear and nonlinear models for the estimation of particulate matter variability. Environmental Pollution 246:89-98.

DOI: 10.1016/j.envpol.2018.11.080

Varotsos C, Efstathiou M, Tzanis C, Deligiorgi D. 2012. On the limits of the air pollution predictability: The case of the surface ozone at Athens, Greece. Environmental Science and Pollution Research 19:295-300. DOI: $10.1007 / \mathrm{s} 11356-011-0555-8$ 